\title{
A Study of Nabokov's Humbert in the Light of Karen Horney's Psychoanalytical Theory
}

\author{
Hossein Sharifi ${ }^{1}$, Shamsoddin Royanian ${ }^{2}$, Omid Ghahreman ${ }^{3}$
}

\author{
${ }^{1}$ Department of English Literature, Semnan University, Iran \\ ${ }^{2}$ Assistant Professor, Department of English Literature, Semnan University, Iran \\ ${ }^{3}$ Assistant Professor, Department of English Literature, Khayyam University of Mashhad, Iran
}

Received: 01 Oct 2021; Received in revised form: 02 Nov 2021; Accepted: 10 Nov 2021; Available online: 19 Nov 2021 (C)2021 The Author(s). Published by Infogain Publication. This is an open access article under the CC BY license (https://creativecommons.org/licenses/by/4.0/).

\begin{abstract}
This study analyses Humbert Humbert's character in the light of Karen Horney's psychoanalytical theory. For this analysis, the study focuses on the main characteristics of Horneyan psychoanalysis and traces them back in the context of Lolita. The results reveal that Humbert's family environment and cultural forces played an important role in shaping his identity. Even though he showed the characteristics of a detached and aggressive personality, he never stopped in his search for glory. Horneyan psychoanalysis of this character not only demonstrated Humbert tendency to move against people but also showed that Nabokov was quite successful in portraying the role of family environment and cultural forces in shaping the structure of neuroticism. Furthermore, Horneyan psychoanalysis helps us recognise the existing conflicts at the heart of this fictional character, allowing us to experience this novel more intensively, intellectually, and emotionally.
\end{abstract}

Keywords-Cultural Studies, Neuroticism, Literature, Psychoanalysis, Personality.

\section{INTRODUCTION}

To study literature and psychology together, one can have an excellent analysis of the human mind. Psychology also helps us recognise the conflicts that exist at the heart of the fictional characters. It, therefore, allows us to experience literature more intensively and emotionally. In an article titled "A Parody of Psychoanalysis in Vladimir Nabokov's Lolita" (2018), the researcher of this study demonstrated how it is impossible to have a Freudian psychoanalytic interpretation of this novel. To further the claim and add to it, he now tries to explain Humbert's behaviour through a Horneyan Psychoanalysis. By doing this, there is a hope to understand the novel in a better way and indicate how successful Nabokov was in portraying the role of family environment and cultural forces in shaping one's neurotic behaviour.

Lolita is the story of 36-year-old Humbert, a literature lecturer, obsessed with Dolores Haze, a twelveyear-old girl. The novel begins with a foreword written by an imaginary editor, and two parts and the author's afterword follows it. In the foreword, the editor explains that Humbert's lawyer has given him Lolita's story, and Humbert passed away in prison when he was waiting for the trial. In this story, Humbert addresses the reader as his jury and wants everyone to understand him. The first part of the story opens with Humbert's background, his family, his childhood, and his first love, Annabel Leigh. When he was twelve years old, he madly fell in love with Annabel, a thirteen-year-old girl, but they never had time for consummation since Annabel died in Corfu of typhus.

These traumatic events follow him throughout his life, and the fire of his obsession with nymphets, sexually attractive prepubescent girls, never quenches because they remind him of his Annabel Leigh. When Humbert goes to the United States, he rents a room in the house of Charlotte Haze. There he meets Charlotte's daughter, Dolores, who is only twelve years old at that time. As soon as Humbert sees her, he is enchanted by her. Humbert decides to marry Charlotte to be near Dolores, whom he calls Lolita. 
Humbert, in his mind, plans to kill his wife, and he writes all his memory and ideas in a notebook. When Charlotte finds out about Humbert's secret plans and obsession, she runs out of the house. At that moment, accidentally, a car hits her, and she dies. Lolita is now in the summer camp, and Humbert goes and picks her up. They spend their first night together in a hotel. Downstairs, Humbert goes to the hotel's terrace, and he encounters a man. The man accuses Humbert of not behaving properly to Lolita. The following day, in the morning, Humbert goes to his room, and Lolita wakes up, then they make love together. That day, Humbert and Lolita leave the hotel and travel across the United States.

In the second part of the novel, Humbert is becoming more obsessed with Lolita, and she is becoming more advanced in controlling him. Someone, in the meantime, begins pursuing them. Humbert believes the man is a private detective who wants to catch him red-handed. Beardsley College eventually hires Humbert, and he enrols Dolores in a school. Even though Humbert is very strict towards Lolita, he lets her participate in the school's play. Humbert becomes more possessive and protective when Lolita begins to socialise more with her friends. Finally, he decides to take her on another trip. On their way, Lolita gets sick, and Humbert takes her to the hospital. When he visits her the next day, he finds that Lolita has already left with a man.

The rest of the book is a description of Humbert's life following his lost stepdaughter, Dolores. One day, he gets a letter from Lolita. She is now married and pregnant, and she asks for financial support from her father. Humbert thinks that Lolita has married the same guy who was following them, and he plans to kill him. However, when Humbert finds Lolita, he realises that it was not her husband but Clare Quilty who took her away from him. In the end, Humbert finds Quilty and shoots him to death. He ends up in prison, where he writes his memory down and dies. Lolita also dies of childbirth at the age of seventeen.

Nabokov wrote Lolita in the realm of imagination, memory, and desire - a fertile ground for psychoanalysis. As an anti-Freudian, however, Nabokov set traps to lure the readers into a wrong understanding. According to Zoran (2005),

... Nabokov tries to make palpable the return of the repressed/forgotten/painful, but as an anti-Freudian, he does not dwell on the pain of repressed traumas over abrupt loss. Rather, instead of mourning dwindling prospects, he puts the focus on memory's palpable achievement of conscious and joyful restoration. (p.28)
Hence, Nabokov provided enough information about Humbert's character, motives, and background.

Horney's theory does not have the restrictions of many other psychoanalytic theories since it does not go back into early childhood - pre-oedipal stages and infancy. Horney's explanatory notes and therapeutic tools, like True Self, Idealized Self, Pride, and Tyranny of the 'Shoulds' have made her theory not only different from other psychoanalytic theories but less dogmatic. She highlights the present structure of every individual's personality. Horney challenged the fundamentals of Freudian psychoanalysis by questioning the basics of Libido theory. For Horney, the problem of Libido theory is that the sexual instinct cannot possibly cover all issues in one's psychic life (2000, p.48). She believed that strict adherence to the overwhelming influence of Libido had led to the stagnation of psychoanalysis (pp.57-58). She disagreed with Freudian psychoanalysis and challenged its psychosexual basic. For Horney, one's particular behaviour is a consequence of cultural forces. She objected to Freud's notion of anxiety which results, in her words, either "from a repression of impulses" or "fear of those impulses of which the discovery or pursuit would incur an external danger" (1999, p.75). So, Freud's interpretation is either physiological or psychological; however, Horney believed that we should merge Freud's two views since "the frequency with which sexual impulses generate anxiety is largely dependent on the existing cultural attitude toward sexuality" (p.76).

Freud also believed that anxiety starts at birth, and castration fear follows it. Whatever happens next is based on reactions to those infantile experiences, and they are nothing but mere repetitions. Freud noticed that there was a relation between Libido and anxiety, but he did not realise that anxiety will change and grow over time. Horney, however, believes that anxiety is "not repetition but development" (1999, p.78). She believed that anxiety is not itself an infantile response, but its formation originates in early childhood, and she called it basic anxiety which develops later on in one's life. In Horney's view, neurosis happens when internal conflicts generate anxiety, and to quench the excruciating pain of anxiety, one seeks help from a defensive mechanism. Not only does it help them relinquish their unwanted feelings, but also it makes them even more neurotic. Here, culture and childhood experiences play a vital role in one's troubled life. As Horney said, "In order to understand how the whole development started we have to go back to childhood" (1999, p.79). 


\subsection{Humbert's Childhood Experiences}

Childhood is the most critical stage of man's life in which neurotic conflicts take roots. Different traumatic events may affect a child's future; however, Horney claimed that one could trace all these experiences to a lack of sincere affection. Horney's theory suggests that a difficult childhood causes neurotic needs. These are needs for affection conditioned by anxiety, and as Horney wrote, they include "dependency, insatiability, possessiveness, jealousy" (2000, P.83). As mentioned above, Horney focused on the development of character structure and believed that these attitudes are not repetitions of infantile ones. Even though there may be significant experiences for someone in future, childhood experiences are mainly responsible for developing one's character, either healthy or neurotic.

Humbert was born in 1910 in Paris, and when he was only three years old, his mother died after being struck by lightning during a picnic. Humbert recalls this as "a freak accident" which left him no memory of his mother but "a pocket of warmth in the darkest past" (p.7). He then lives with his mother's sister, Sybil, who is a cousin of his father. Humbert's father married and then neglected Sybil, who was a kind of "unpaid governess and housekeeper" in his immediate family (p.8). She had been in love with Humbert's father, and her rigidity left no place for the growing of genuine affection. Even though Humbert states that "I was extremely fond of her, despite the rigidity the fatal rigidity — of some of her rules," from these early years, there is a lack of affection in Humbert's life. Humbert says, "Perhaps she wanted to make of me, in the fullness of time, a better widower than my father" (p.8); however, he seems to be failing to recognise this lack of genuine affection in the first place. Humbert believes that he had a happy life and grew a healthy child. He believes that everyone liked him, but the reader knows that this likeness was not genuine. For example, he says that

Elderly American ladies leaning on their canes listed towards me like towers of Pisa. Ruined Russian princesses who could not pay my father, bought me expensive bonbons ..., and I adored and respected [my father] and felt glad for him whenever I overheard the servants discuss his various ladyfriends, beautiful and kind beings who made much of me and cooed and shed precious tears over my cheerful motherlessness. (p.8)

If there is any love in his childhood, it is due to other people's own needs or feeling pity for the motherless Humbert. His life may be cheerful to him on the outside, but that is not how he feels. The closest person to him is his father, whom he seems to adore and respect. However, when Humbert's father goes to Italy with Mme de R. and her daughter, Humbert is left alone on his own, and he says, "I had nobody to complain to, nobody to consult" (p.9). The absence of his father in the time of his need shows the lack of genuine affection which deprives him of feeling safety and satisfaction.

Humbert's family environment and childhood experiences play a vital role in developing his character in a neurotic way. When the environment is not favourable enough to help him satisfy the needs for safety, and when his parents fail to provide him with genuine love and satisfaction, he develops basic hostility and redirects his feelings of hostility towards others. Humbert remembers one of his childhood photographs in which he "was sitting somewhat apart from the rest, came out with a kind of conspicuousness: a moody, beetle-browed boy in a dark sport shirt and well-tailored white shorts, his legs crossed, sitting in profile, looking away" (pp.10-11). This photograph clearly shows Humbert's basic hostility towards others.

Children often do not express their hostility, and they usually repress it. This repressed hostility will eventually lead to basic anxiety, which, according to Horney, is the "feeling of being isolated and helpless in a world conceived as potentially hostile" $(2014$, p.18). This anxiety prevents the child from interacting with others, and since communication is what he needs, he adopts one of the three styles, Moving Toward People, Moving Against People, and Moving Away from People, based on their neurotic needs relating to others.

Humber needs love and affection and looks for it everywhere. As mentioned before, the excessive need for love provides a ground for the development of neuroses, and it generates more anxiety and destructive impulses. He is not aware of the destructive nature of his needs. It is only near the end of the novel that he gains a sort of selfrealisation and understands that he was, in his childhood, deprived of genuine kindness with which he could give power to his youth. He says, "I was but an infant, and in retrospect, no yearnings of the accepted kind could I ever graft upon any moment of my youth..." (p.270).

Social inequality and contradictions have also confused Humbert since his early childhood. These contradictions create intrapsychic conflicts and pave the path to lead him towards neuroticism. For example, his relationship with Anabel is against his social class. He stated that they "were unable to mate as slum children would have so easily found an opportunity to do" (p.10). He does not know why it is wrong and why they have to hide it behind a "chance rampant," while some other children can easily have such a relationship. These 
contradictions will follow him ever after, and soon he finds himself maturing "amid a civilisation which allows a man of twenty-five to court a girl of sixteen but not a girl of twelve" (p.15). One can find various contradictions in the society which create intrapsychic conflicts for both healthy and neurotic people. While healthy people can easily cope with these conflicts, for the neurotics, these contradictions intensify their neurotic needs and inner conflicts "to a degree that makes any satisfactory solution impossible" (1999, pp.288-289).

Humbert's reaction to his living environment and cultural experiences may eventually show itself in different ways. Based on Horney's theory, Humbert as a neurotic may try first to manage his behaviour to satisfy the people around him; he may move toward others. He may also try to move against people and be aggressive, or if he cannot satisfy his needs, he may move away from people. These three styles are in contradictions with one another, and they intensify the tension or Humbert's underlying conflict even more.

\section{HUMBERT'S INTERPERSONAL RELATIONSHIPS}

An interpersonal relationship is a deep association between two or more people that thrive through the context of social and cultural relations ("Interpersonal Relationships,"n.d.). Everyone has the potential for healthy development, but they need a healthy environment for growth. This section explores the association between Humbert and other people through the context of social and cultural relations in Lolita. It considers Humbert's interpersonal relationship as a symptom and discusses how Humbert's childhood experiences shape neurotic or healthy behaviours in him psychoanalytically. First, this section traces back the external factors in shaping Humbert's behaviour to see whether or not he moves towards healthy development. Then, it focuses on Humbert's reaction to his living environment and childhood experiences - Is he moving toward people, against people, or away from people?

\subsection{Moving Toward People}

When a child does not develop a feeling of safety, and instead he develops a sense of insecurity, he will feel basic anxiety. In Horney's words, "It is his feeling of being isolated and helpless in a world conceived as potentially hostile" (2014, p.18). The pressure of this basic anxiety pervades his social relationship. The child, therefore, will always be looking for ways to cope with his anxiety - not to arouse or increase the underlying anxiety. A way to cope with the basic anxiety is to cling to people around oneself or seek love everywhere. Horney wrote, "When moving toward people [one] accepts his own helplessness, and in spite of his estrangement and fears tries to win the affection of others and to lean on them" (1945, p.42). The person does not have this love in himself, so he tries his best to get others' love and attention. Hence, he moves toward people.

For example, when Humbert was a child, before meeting Annabel, everyone liked him, and when he went to school, "[he] was on perfect terms with schoolmates and teachers alike" (p.8). After meeting Annabel, he put all his effort into getting her love. If someone does not satisfy the demands of a neurotic person, he considers it as a rejection. According to Horney, "a rebuff not only throws them back on their basic anxiety but is also considered equivalent to humiliation" which arouses excruciating anger ((1999, p.135). Horney described four possible means of getting affection as: "bribery; an appeal to pity; an appeal to justice; and finally threats." She added, "Several of them may be employed simultaneously or in alternation, depending on the situation ..., and depending on the degree of hostility" (p.139). Humbert, for instance, is ready to offer all he has to Annabel, which is comparable to an act of bribery. He said, "with a generosity that was ready to offer her everything, my heart, my throat, my entrails, I have her to hold in her awkward fist the scepter of my passion" (p.12). Humbert tries to do his best to satisfy his needs and win others affection. As the narrator of his story, he wrote, "Humbert tried hard to be good. Really and truly, he did" (p.17). However, after the shock of Annabel's death, Humbert fails to receive genuine affection. Humbert needs to organise his behaviour to suit the people around him; hence, he represses this neurotic trend and follows the other ones.

Humbert stubbornly insists that his relationship with Lolita is nothing but love. Although it looks exceedingly difficult to say what love is, it is easy to say what is not love. It is incompatible with the idea of love when Humbert is using Lolita only as a means for some purpose. As Horney said, "A person may deceive himself into believing that he loves another ..." (1999, p.108). A considerable confusion between genuine love and compulsive needs originates this illusion of love in neurotic people. Humbert, accordingly, tries to attribute his neurotic thirst to the passion of true love. Deep down in his unconscious mind, Humbert feels guilty about depriving Lolita of her future. That is why Humbert addresses his readers or the "Sensitive gentlewomen of the jury" to highlight his passion and true love (p.127). In other words, Humbert wants to justify his mal-intent. He believes that he is madly in love with Lolita and wants everyone to know it to prove himself. Humbert addressed the readers 
and wrote, "You see, I loved her. It was love at first sight, at last sight, at ever and ever sight" (p.253). Nevertheless, it seems that Humbert is not aware of his neurotic needs beneath his love for Lolita.

As Horney said, "The neurotic need for affection often takes the form of a sexual infatuation or an insatiable hunger for sexual gratification" (1999, p.147). In his childhood, Humbert, with his complaint tendencies, craved sexual infatuation. However, he had to repress his sexual desires because, under the eyes of the adults, he never had the chance to explore his Annabel sexually. Moreover, once they were alone on a deserted beach, two passers-by interrupted them. Humbert says, "I was on my knees, and on the point of possessing my darling..." when these two men "came out of the sea with exclamations of ribald encouragement" (p.11). This humiliation and the frustration of not discovering Annabel continue to haunt him all his life. After Annabel's death, a considerable change occurred in Humbert's personality, and it was then that the rift in his life began (p.11). Later on, Humbert may not necessarily follow the characteristics of the complaint type, such as helplessness, self-sacrificing, and compulsive need for affection. His sexual inclinations, however, may still demonstrate a disguised and repressed tendency for getting affection. In the following section, there are some concrete examples of events in the story or in the behaviour of the main character which show this repressed tendency.

\subsubsection{The Role of Sexuality in Humbert's Life}

Sexuality may play a different role from an individual to the other. Horney classified the role of sexuality in every individual into two groups. In the first group, individuals contact with almost everyone compulsively, and they keep having various relationships. (1999, p.152). While a college student, Humbert tries to sate his lust by engaging in various relationships. As he said, "in London and Paris, paid ladies sufficed [him]" (p.13). Humbert gradually comes to notice that these relationships will never reduce his underlying anxiety. He thinks he knows his problem and becomes his own personality's analyst. He wrote,

No wonder, then, that my adult life during the European period of my existence proved monstrously twofold. Overtly, I had so-called normal relationships with a number of terrestrial women having pumpkins or pears for breasts; inly, I was consumed by a hell furnace of localised lust for every passing nymphet whom as a law-abiding poltroon I never dared approach. (p.13)

At first, Humbert unconsciously wanted to get others' affection and move toward people by engaging in various sexual relationships. However, due to his increasing inhibition, he moves toward having very few relations. For example, after getting a divorce from Valeria, despite his excruciating desires, Humbert is mentally incapable of sexual intercourse. This incapability leads him to insomnias. When he goes on an expedition into arctic Canada, Humbert tries to engage in sexual intercourse with Dr Anita Johnson, which never happens very successfully (p.29). After coming back from the expedition, he spends some months in a sanatorium. There he discovers that they call him "potentially homosexual" and "totally impotent" (p.31).

As Horney said, there is a sub-group relating to the first group in which men and women have very few relations due to having more inhibitions. However, they create a sort of erotic atmosphere in their relationships (1999, p.152). The more his sexual inhibitions grow, the more he creates such erotic atmospheres. In his later relationships, Humbert manifests it obviously. For example, when he marries Valeria, he asks her to wear children's clothes. He wrote,

After a brief ceremony at the mairie, I took her to the new apartment I had rented and, somewhat to her surprise, had her wear, before I touched her, a girl's plain nightshirt that I had managed to filch from the linen closet of an orphanage. I derived some fun from that nuptial night and had the idiot in hysterics by sunrise. (p.23)

It does not matter whether or not he is attracted to Valeria. Humbert creates an erotic atmosphere that helps him go a bit through his anxiety; his inhibitions, however, grow exponentially. Humbert, as the narrator of his own story, states, "All of which goes to show how dreadfully stupid poor Humbert always was in matters of sex" (p.22).

\subsection{Moving Against People}

In healthy individuals, the feeling of power or prestige originates as a result of the realisation of their superiority. The desire to dominate, to achieve prestige, and to gain wealth, is not in itself neurotic. What makes these individuals neurotic is the compulsive nature of their needs. According to Horney, "The neurotic striving for power, however, is born out of anxiety, hatred and feelings of inferiority" (1999, p.163). These neurotics are unaware of their feelings of inferiority, but they often show the existing conflicts in their dreams. For example, in his dreams, Humbert shows such a feeling of inferiority. He wrote,

Sometimes I attempt to kill in my dreams. But do you know what happens? For instance I hold a gun. For instance I aim at a bland, quietly interested enemy. Oh, I press the trigger all right, but one bullet after another feebly drops on the floor from the sheepish 
muzzle. In those dreams, my only thought is to conceal the fiasco from my foe, who is slowly growing annoyed. (p.43)

It is essential to know that Humbert had this dream before writing his manuscript, and by that time, he could not detect his feeling of inferiority. This dream shows Humbert as a helpless, subdued and despicable creature, which is in contrast with his own self-image as a powerful man. This dropping of bullets from "the sheepish muzzle" manifests Humbert's feeling of inferiority and embarrassment.

Humbert clings to power and prestige because of his inner helplessness. Hostility for him appears in the form of a tendency to be domineering. He tries to dominate everyone, especially young people, because he thinks they are weak, or he feels superior to them. For example, in his relationship with Monique, Humbert tries his best to dominate her. However, after getting control over Monique, he suddenly stops his relationship. By subduing to Humbert, young Monique becomes like any other women to him. He wrote, "she seemed to have grown less juvenile, more of a woman overnight...." (p.20). No one is important to him, even Lolita, with whom he believes he is madly in love. Lolita was like Humbert's Anabel and represented his imaginary interpretation of a nymphet. "[She] was the same child - the same frail, honey-hued shoulders, the same silky supple bare back, the same chestnut head of hair" (p.35). However, Humbert ignores Lolita's feelings almost all the time. Humbert wrote, "Now, squirming and pleading with my own memory, I recall that on this and similar occasions, it was always my habit and method to ignore Lolita's states of mind while comforting my own base self”' (p.270).

Because Humbert constantly asserts himself as the strongest, the cleverest, and the most powerful, he tries his best to develop the needed efficiency. As Horney stated, "The zest and intelligence [the neurotic] puts into his work may make him a highly esteemed employee or a success in a business of his own" (1945, p.67). When Humbert is in New York, a war-time university asks him to complete the history of French literature for English students, which requires Humbert's intellectual and physical effort. He wrote, "[t]he first volume took me a couple of years during which I put in seldom less than fifteen hours of work daily" (p.29). Therefore, his zest and intelligence make him a success in every work he does. Humbert wants to become the centre of attention. He wants to be very important and be recognised for his accomplishments due to his compulsive need for power. Humbert wants to obtain freedom by crossing the boundaries of social and moral codes.
Humbert marries Charlotte to be near Lolita. He wants to be alone with Lo and even plans to kill Charlotte. He becomes more and more obsessed with Lolita, and when Charlotte dies in a car accident, he seduces Lolita by threatening to put her in a children's home. Contrariwise, Humbert claims that it was Lolita who seduced him. Whatever Humbert does, shows his inveterate tendency to move against people. Humbert is telling his so-called love story, but he is unconsciously jostling for everyone's attention. His love for Lolita manifests a longing for superiority. He declared, "You may jeer at me, and threaten to clear the court, but until I am gagged and halfthrottled, I will shout my poor truth. I insist the world know how much I loved my Lolita ..." (p.261).Moreover, in narrating his story and love, he holds an ideal and rightful place for himself. He wrote, "I am no poet. I am only a very conscientious recorder" (p.67). His attitudes may reveal traces of repressed longing for getting affection. Humbert may hurt his Lolita, but he will be deeply compassionate forthwith (p.208). Gaining control over Lolita becomes Humbert's central motif to revive his helpless self, preventing him from feeling inferior or humiliated. He wrote, "How smugly would I marvel that she was mine, mine, mine, and revise the recent matitudinal swoon to the moan of the mourning doves" (p.150). When Humbert fails both in satisfying his complaint and aggressive needs, and there is no way for him to gain control over Lolita, his repressed detached needs reveal themselves.

\subsection{Moving Away from People}

There are moments in Humbert's life when he develops a detached personality and becomes an onlooker at himself. Horney believed that if one's neurotic needs are not satisfied through the other trends, he may adhere to aloofness (1945, p.74). That is why Humbert shows more characteristics of the detached type after every traumatic event or harrowing experience. He first tries to satisfy his needs by clinging to affection or power, but when it fails, he desperately clings to detachment. In his childhood, there were times Humbert failed to receive genuine affection. As a result, he was often "sitting somewhat apart from the rest, came out with a kind of dramatic conspicuousness: a moody, beetle-browed boy in a dark sport shirt..." (p.10). Humbert's intrapsychic conflicts make him withdraw from his inner battlefield. He often lives as if he is in a theatre watching a play on the stage. Especially after Annabel's death, his feeling of detachment proliferates, and he hides in his imaginary world of nymphets. When Humbert comments on his own behaviour, "oh, how you have to cringe and hide!" he is manifesting his growing feeling of detachment where he is drowning in his thoughts and laying his traps. He wrote, "I 
am like one of those inflated pale spiders you see in old gardens. Sitting in the middle of a luminous web and giving little jerks to this or that strand" (p.45). The detached type always wishes to be aloof, but Humbert's aggressive needs are too strong to let him continue his aloofness for too long. The detached type personalities refuse to face their inner conflicts, but if they happen to feel these conflicts, they will be anxious and terrified. That is why they try to justify their attitudes. Humbert believes that Lolita seduced him to reject the influence of his aggressive self. He keeps saying that "it was she who seduced [him]" (p.124).

\section{HUMBERT'S INTRAPSYCHIC CONFLICTS}

These three neurotic trends are in contradictions with one another, so they intensify Humbert's inner tension and stress. Conflicts between his opposing needs and wishes create intrapsychic conflicts for Humbert, making him soon become more and more alienated from his real self. This alienation has a considerable influence on Humbert's interpersonal experiences as well. Humbert, in his unconscious mind, keeps feeling of being unsafe, unloved, and unvalued. To reduce this inner conflict and fight against this tension, he needs to adopt some intrapsychic strategies. Horney identified three interpersonal strategies with which someone fights against the feeling of being unsafe, unloved, and unvalued: Expansive solution, Selfeffacing solution, and Resigned solution. As the expansive type, Humbert wants to gain mastery over his life. There are three expansive solutions, the narcissistic, the perfectionist, and the arrogant-vindictive (Horney, 2014, p.76). Humbert works towards the narcissistic solution by holding onto his exaggerated claims. He believes that he is a handsome and seductive one, and therefore, he can possess everyone. Humbert wrote, "Let me repeat with quiet force: I was, and still am, despite mesmalheurs [my misfortunes], an exceptionally handsome male; slowmoving, tall, with soft dark hair and a gloomy but all the more seductive cast of demeanor" (p.22). Self-glorification is a means for Humbert with which he can actualise his idealised self. More precisely, Humbert is his idealised self-image, and he adores it. The actualisation of the idealised self raises Humbert's false confidence. According to Horney,

[The narcissistic] has (consciously) no doubts; he is the anointed, the man of destiny, the prophet, the great giver, the benefactor of mankind. All of this contains a grain of truth. He often is gifted beyond average, early and easily won distinctions, and sometimes was the favored and admired child. (2014, p.94)
Humbert's sense of superiority lies in his belief that there is no one he cannot win. He even believes that he can melt the heart of his readers or the jury. No matter how valuable they are to him, he must impress them. The fact that others have wishes of their own or expect something of him arouses resentment in Humbert as a narcissistic.

\subsection{Humbert's Idealised Self-Image}

As already mentioned, Humbert did not experience the feeling of safety in his childhood. Lack of genuine love and affection deprived him of the development of selfconfidence. Instead of moving towards self-realisation, therefore, he moved towards self-alienation and created an idealised self-image. By self-idealisation, Humbert will be able to experience a feeling of power, significance, and superiority over others. According to Horney, when neurotics continue to believe in their idealised self-image, they try to integrate it into all parts of their lives, particularly their relationship with others. (2014, p.24). Similarly, Humbert idealised image finds meaning only in his relations with others. That is why when Humbert embarks on an expedition into arctic Canada when he is away from people, he has fewer inner conflicts. He wrote,

Surrounded by such dejected vegetation as willow scrub and lichens; permeated, and, I suppose, cleansed by a whistling gale; seated on a boulder under a completely translucent sky ..., I felt curiously aloof from my own self. No temptations maddened me. (p.30)

He may not like his loneliness and feels depressed in such a dejected place because he needs others to give meaning to his idealised self-image. When he feels aloof from his own self, it is not an aloofness from his real self. Humbert fails to understand that his idealised self-image is fading away in the absence of any civilisation, and he takes it as his real self.

Humbert seems to have formed an idealised selfimage, in which the rules of the ordinary man does not influence him. He created this idealised image based on his earlier fantasies and needs. On the one hand, he yearns to return to his lost Annabel Lee, but on the other hand, he wants to return to his lost self-confidence and feeling of safety in a world that is potentially hostile. Humbert, soon in this world, begins to lose touch with his real self and believe in the reality of his idealised self-image. If something appears contradictory to his idealised image, he needs to restrict or modify it. Humbert used to hide his real self because it was contradictory to the idealised one. He also expects everyone to treat him based on his idealised self, and if they do not treat him so, they will intensify the underlying rage or anxiety in Humbert. 
As mentioned above, Humbert became alienated from his real self. All he knows about himself is nothing but mere conjecture. He addressed his reader and wrote, "Gentlemen of the jury! I cannot swear that certain motions pertaining to the business in hand — if I may coin an expression - had not drifted across my mind before... There may have been times - there must have been times, if I know my Humbert...." (p.64). To believe in his idealised self-image, Humbert needs to confront reality and disregard evidence. According to Horney, one confronts reality by implementing alternative techniques: "He forgets; it does not count; it was accidental; it was on account of circumstances, or because others provoked him; he could not help it, because it was natural" (2014, pp.3637). Similarly, Humbert believes that Lolita began with Annabel and that no one can help it. To him, it sounds natural that he has to break Annabel's spell by "incarnating her in another" (pp.11-13). Moreover, Humbert sees himself as a victim of Lolita's seduction and believes that it was Lolita who provoked him (p.124).

Writing Lolita's manuscript, Humbert begins a journey to a state of self-realisation. When he finds out that Lolita is now married and pregnant, and she has no intention to come back to him, his idealised self-image shatters into pieces. He then partially understands his real self and writes, "I was weak, I was not wise, my schoolgirl nymphet had me in thrall" (p.171). However, he will never succeed in coming to full self-realisation. By the end of the book, he manifests his idealised self-image as a protective father who wants to prove his own self again by protecting his needy child, Dolores (pp.290-291).

\subsubsection{Humbert's Search for Glory}

Since Humbert firmly believes in his idealised self-image, he demonstrates it in all aspects of his life, particularly his relations with others. Instead of moving towards an understanding of the true self, he moves more and more towards the glorification of his idealised self. This movement represents a search for glory, and according to Horney, it includes "the need for perfection, neurotic ambition, and the drive toward a vindictive triumph." She added that all these elements are always present, but their degrees and awareness differ in every individual (2014, p.24).

Humbert's needs for perfection dominate his personality. He wants to become perfect in every aspect of his life. However, some taboos strangulated him, and these taboos are against his inner tyranny of the shoulds (p.16). To prove his idealised self, Humbert needs to be with young nymphets. He needs to kill Charlotte and get away without being caught. Humbert compulsively needs to satisfy the readers and everyone to prove his individuality and strength. He is "far from feeling any relief" after murdering Clare Quilty, and he even feels a more substantial burden on his shoulders because no one cares that Humbert murdered him (pp.285-286). Quilty was nothing more than a despicable creature in the story, and his death was not important even for his own friends. Therefore, Humbert cannot satisfy his needs for perfection even after murdering Quilty, and his last opportunity will be to show his power and superiority to the reader. Throughout Humbert's story, the readers hear Humbert's unconscious voice, that he wants himself to endure and understand everything, and that he wants to be above others and reach perfection. The second element in the neurotic search for glory is neurotic ambition. The content of ambition may change several times. For example, Humbert has always wanted to prove his superiority by having the most desirable nymphets, but at the end of the novel, he wants to prove his superiority by melting the heart of the readers or becoming the protective father.

Humbert's continuing inner conflicts are serious. There is always "Humbert the Terrible" against "Humbert the Small" fighting together (p.25). Humbert the Small has been deprived of his self-confidence and his fundamental rights. Humbert the Terrible, on the other hand, wants to deprive others and show Humbert's real success by defeating them. He said, "not for a second did I forget the load of revenge" (p.241). Unconsciously, Humbert hopes that his success in domination over others will satisfy his desire for revenge, which is another aspect of a search for glory - a drive toward a vindictive triumph (Feist, 2008, p.175). Horneyan analysis of Humbert's inner conflicts, therefore, shows that he is continually trying to become perfect again, to fulfil his ambitions, and achieve success in a search for his glory.

\subsubsection{Humbert's Neurotic Claims}

Humbert tries to disregard reality because he unconsciously believes that he is right, and there is something wrong all around him. In his search for glory, he wanders across the realm of his imagination. Interestingly, Humbert expects others to treat him based on his imagination and idealised self-image. Humbert believes that his imagination can do anything; hence, he exaggerates the importance of imagination even more. This exaggeration is a characteristic of Humbert's neurotic claims to justify them. He also exaggerates his attractiveness to meet his neurotic claims. Since, in his imagination, he thinks that he can melt the heart of everyone and every woman, he needs to exaggerate his characteristics. He stated,

But every once in a while I have to remind the reader of my appearance much as a professional novelist, 
who has given a character of his some mannerism or a dog, has to go on producing that dog or that mannerism every time the character crops up in the course of the book. (p.97)

Furthermore, when it is against his morals to deprive Dolores of her rights, Humbert exaggerates her seductive characteristics and that she was the one who seduced him into having sexual intercourse.

Humbert spends all his energy justifying his claims; however, he becomes frustrated when he does not receive the proper reaction to his claims. According to Horney, there are different reactions to the rage building up inside neurotics. A reaction to rage, according to Horney, is to "plunge into misery and self-pity" (2014, pp.56-57). In Humbert's poem for Clare Quilty, which he calls "poetical justice," not only one may see the state of his misery and self-pity, but also they may see the vindictiveness of Humbert's suppressed rage. He wrote,

Because you took advantage of a sinner / because you took advantage / because you took / because you took advantage of my disadvantage [...] / because of all you did / because of all I did not / you have to die. (pp.281-283)

Humbert wants to blame Quilty for his own imperfect self, and his overemphasis on justice is a mere disguise for vindictiveness. One can find traces of vindictiveness all over Humbert's life, and it is not only in his relationship with Quilty. For example, when Valeria, his wife, tells him that she is in love with someone else, even though Humbert does not love her at all, he is burning with rage. He first tries to repress his anger, but he shouts at last and strikes her on the knee with his fist (p.25). Moreover, when Valeria's lover goes to the toilet of Humbert's house, he forgets to flush the toilet. This incident fills Humbert with "fierce disgust" because it is against his neurotic claims (p.26). In his imagination, prestigious Humbert is above others and has control over them. When they challenge his neurotic claims, Humbert's anger will be rising. The more he is choked with rage, the less power he has over his imagination. That is why after Lolita denies Humbert's neurotic claims, he does not see her through the lens of his imagination anymore. After that, Lolita will be an ordinary woman to him and not his imaginary nymphet. He wrote,

How wrong I was. How mad I was! Everything about her was of the same exasperating impenetrable order - the strength of her shapely legs, the dirty sole of her white sock, the thick sweater she wore despite the closeness of the room, her wenchy smell, and especially the dead end of her face with its strange flush and freshly made-up lips. (p.191)

\subsection{Humbert's Self-Hatred}

There are moments that Humbert realises his real self is different from his idealised self-image. He begins to hate his real self in these moments because he is looking at it from a higher perspective. Under a tyrannical system of shoulds, Humbert's demands on his real self increase. Humbert should melt the heart of everyone, even the readers, and people should understand him. He should always continue his love and seek revenge for his lost Annabel Lee because " $[\mathrm{t}]$ here are things that should never be given up" (p.196). These shoulds deprive Humbert of his inner freedom, and they intensify his self-hatred because he cannot always yield to these unreasonable demands. In other words, one can say that these relentless demands are an expression of Humbert's self-hatred. Another expression of self-hatred is Humbert's merciless self-accusation.Humbert continuously criticises himself, and this criticism usually takes the form of questioning the value of his motives. One may see the depth of these selfaccusations in the nicknames Humbert has given himself. Once, he names himself "Humbert the Small" or "Humbert the Terrible." Another time he calls himself "Humbert the Hoarse" or "Humbert the Wounded Spider." However, his bitterest self-accusation is when he names himself "Humbert the Popular Butcher" (p.25, p.44, p.50, p.101). These accusations show that hatred has flared up inside Humbert.

He also shows his self-hatred by means of selfcontempt. As mentioned before, Horney believed that selfcontempt could take the form of "self-belittling, selfdisparaging, self-doubting, self-discrediting, selfridiculing" (2014, p.132). Humbert states, "Despite my manly looks, I am horribly timid" (p.49). This selfbelittling is a form of Humbert's self-contempt. One can also see Humbert's self-discrediting and self-ridiculing attitude when he states, "I am lanky, big-boned, woolychested Humbert Humbert, with thick black eyebrows and a queer accent, and a cesspoolful of rotting monsters behind his slow boyish smile" (p.40). It is important to note that Humbert addresses himself with the first-person "I" at the start but then switches to third-person "his" at the end of his statement. It shows Humbert's self-contempt and the fact that he does not like his real self. Apart from Humbert's self-ridiculing, his self-torment is another means of showing self-hatred. Humbert knows that by engaging Dolores sexually, he is turning to violence. This action of victimisation increases Humbert's sense of guilt. Humbert, however, gains immense pleasure from this act of violence. His self-torment does not have a masochistic origin since he never enjoys hurting himself. On the other hand, Humbert only wants to satisfy his neurotic needs caused by a variety of conflicts and anxieties. 


\section{CONCLUSION}

This study aimed to analyse Humbert's character in the light of Karen Horney's psychoanalytical theory. The results revealed the importance of Humbert's family environment and cultural forces in shaping his identity and moving him against people. His family environment was not favourable enough to help him satisfy the needs for safety. His parents failed to provide him with genuine love and satisfaction; thus, he developed basic hostility. Social inequality and contradictions in the culture and civilisation also confused Humbert since his early childhood. These contradictions created intrapsychic conflicts and paved the path to lead him towards neuroticism. Humbert could not develop a feeling of safety and instead developed a sense of insecurity. This feeling of insecurity intensified Humbert's basic anxiety. To cope with the basic anxiety, Humbert first clung to people around him and sought love everywhere. However, after the shock of Annabel's death, Humbert became dissatisfied with getting genuine affection, and that was when he began to repress his complaint needs. Lack of genuine love and affection also deprived him of the development of self-confidence. Instead of moving towards self-realisation, therefore, he moved towards self-alienation and created an idealised self-image. Since his idealised self-image was in contrast with his real self, Humbert's inner conflicts grew exponentially. Eventually, through writing his story as a sort of self-analysis, Humbert could quench the fire of his inner conflicts, but he never stopped in his search for glory. Horneyan psychoanalysis of this character not only demonstrated Humbert tendency to move against people but also showed that Nabokov was quite successful in portraying the role of family environment and cultural forces in shaping the structure of neuroticism. Furthermore, Horneyan psychoanalysis helped us recognise the existing conflicts at the heart of this fictional character, allowing us to experience this novel more intensively, intellectually, and emotionally.

\section{REFERENCES}

[1] Feist, J., \&Fiest, G. J. (2008). Theories of Personality. Boston: McGraw-Hill. Perfect, T. J., \& Schwartz, B. L. (Eds.) (2002). Applied metacognition Retrieved from http://www.questia.com/read/107598848

[2] Horney, K. (2000). New Ways in Psychoanalysis. New York: W.W. Norton.

[3] Horney, K. (2014). Neurosis and Human Growth: The Struggle Toward Self-Realisation. London: Routledge, Taylor \&amp; Francis Group.

[4] Horney, K. (1945). Our Inner Conflicts: A Constructive Theory of Neurosis. New York: Norton.
[5] Horney, K. (1999). The Neurotic Personality of Our Time. London: Routledge.

[6] Interpersonal Relationships. (n.d.). In Wikipedia. Retrieved September 21, 2020, from https://en.wikipedia.org/wiki/Interpersonal_relationship

[7] Nabokov, V. V. (1996). Lolita. In V. V. Nabokov (Author), Novels, 1955-1962: Lolita, Pnin, Pale Fire, Lolita a screenplay (pp. 1-298). New York, NY: Literary Classics of the United States.

[8] Sharifi, H. (2018). A Parody of Psychoanalysis in Vladimir Nabokov's Lolita. Journal of English Language and Literature, 9(2), 823. doi:10.17722/jell.v9i2.325

[9] Zoran, K. (2005). Strong Opinions and Nerve Points: Nabokov's Life and Art. In J. W. Connolly (Author), The Cambridge Companion to Nabokov (pp. 11-30). Cambridge University Press. 